\title{
How Do Organizational Commitment and Work Engagement Mediate Between Human Resource Management Practices and Job Performance?
}

\author{
Quaisar Ijaz Khan ${ }^{\text {a }}$, Raheel Mumtaz ${ }^{\text {b }}$, Muhammad Farooq Rehan ${ }^{c}$ \\ ${ }^{a}$ Assistant Professor GC University Faisalabad, Pakistan \\ ${ }^{\mathrm{b}}$ Assistant Professor GC University Faisalabad, Pakistan \\ ${ }^{c}$ Assistant Professor GC University Faisalabad, Pakistan \\ Email: farooq.rehan@gcuf.edu.pk
}

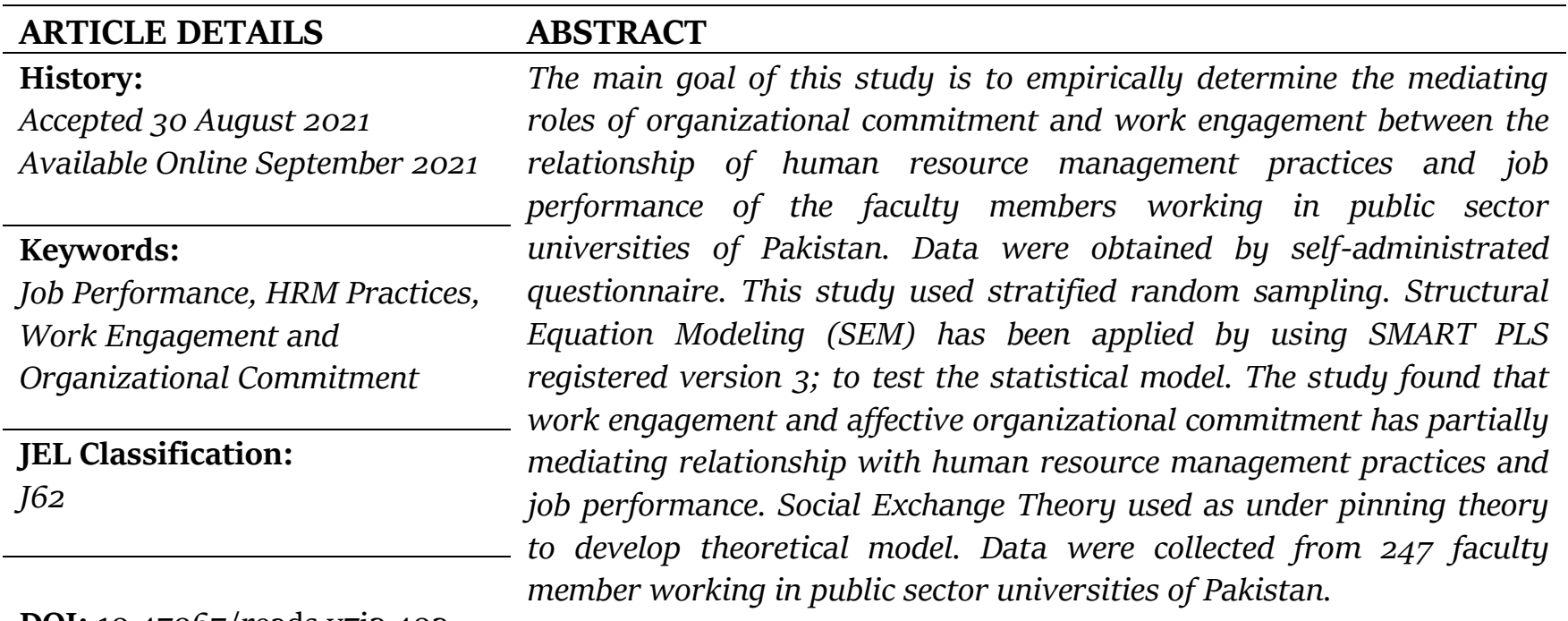

DOI: $10.47067 /$ reads.v7i3.403

(C) 2021 The authors. Published by SPCRD Global Publishing. This is an open access article under the Creative Commons Attribution-

NonCommercial 4.0

Corresponding author's email address: farooq.rehan@gcuf.edu.pk

\section{Introduction}

Because of the significant costs associated with decreased efficiency and production, as well as the costs associated with needing to hire and educate newcomers, employee turnover has long been a primary concern of scholars, human resource practitioners, and managers in service sectors (Utami, Sapta, Verawati, \& Astakoni, 2021). Retaining the potential workforce of public sector universities is now becoming challenging. when individuals are dissatisfied with their positions or devoted to their organization, prompting them to look for new alternatives. If they locate a better opportunity, turnover will be unavoidable (Muisyo, Qin, Ho, \& Julius, 2021). The secret to successfully running a private university is to satisfy the best staff or faculty. In today's market, competition is expanding year after year. New universities are emerging on the market, as are overseas colleges via the internet, which is why retaining the best faculty is critical for competing and maintaining a competitive edge (Rabiul \& Yean, 2021; Yudianto, Mulyani, Fahmi, \& Winarningsih, 2021). Job satisfaction is favorably connected with favorable work outcomes like organizational commitment and negatively associated with negative 


\section{Review of Economics and Development Studies, Vol. 7 (3) 2021, 465-474}

outcomes like turnover intention. Employees' positive work attitudes and contributions contribute to an organization's competitive advantage (Baltaru, 2019).

HRM practices can be defined as a set of internally coherent and consistent procedures intended at reinforcing and promoting employee competence, motivation, and commitment. In order to meet the organization's objectives, they also manage people abilities and skills, training and development, working environment, supervisory support, promotion opportunity, performance appraisal are more likely to create work conditions and environments in which employees are highly committed to the organization and do their best to achieve the organization's goals and enhance job performance (Côté, Lauzier, \& Stinglhamber, 2021; Rabiul \& Yean, 2021; Zhang, Jiang, Liu, \& Liu, 2020). They do not pay adequate compensation to their employees, which leads to employee unhappiness and increased the likelihood of staff turnover. As a result, it is easy to claim that high turnover is a severe concern for the institutions of higher education in Pakistan. Organizational commitment might be regarded as a potential mediator in the interaction between human resource practices and turnover intentions (Rabiul \& Yean, 2021).

In order to attain corporate competitiveness, a higher level of mutual trust among members and between management and employees may be able to maintain and sustain human talents. Leadership is critical to establishing trust in organizations, according to previous study. Employees, for example, will tend to assist their leaders in accomplishing organizational goals if they believe their leaders care about their interests and treat them fairly (Aina, Bratti, \& Lippo, 2021; Li et al., 2021). HRM practices refer to institutional actions that focus on human resource management to achieve institutional objectives.

Whilst employee engagement is defined as the degree to which employees identify with and participate in a company. Individual faculty commitment to the academic institution is referred to as faculty organizational commitment (Gieter, Hofmans, \& Pepermans, 2011; Loan, 2020).

However, work engagement is conceptualized as a tridimensional construct consisting of vigor, devotion, and absorption (Côté et al., 2021). The amount of mental energy a person has, his willingness to put that energy to work, and his persistence in doing so are all defined as work engagement. Dedication in the workplace refers to an employee's sense of purpose, inspiration, pride, and challenge. Absorption refers to the level to which an employee is so focused and concentrated on the task at hand that time goes quickly and with little distraction while at work. According to Shaufeli and Bakker (2002), the signs of employee engagement are feeling full of energy, being able to work for a long time, inspiring work, excited about work, proud of work, time passing quickly when working, and seeking to get away from work. However, job performance refers to the highest level of production achieved after completing successful tasks throughout working hours. Job performance, on the other hand, is a positive behavior of employees who put out atheistic effort. With the effective administrative practices of the higher authorities, the employees perform well in achieving the organizational objectives. It is the employees' constructive attitude toward the development of educational institutions (Chunyu \& Liping, 2021).

Whereas job performance refers to the highest level of output achieved after completing successful tasks throughout working hours. It is the employees' constructive attitude toward the development of educational institutions (Kaur, 2011; Quaisar, Shukor, \& Soffian, 2016). Surprisingly, little thought has been given to the impact of these human resource management strategies on job

performance. The study generates the following research questions keeping in view the early discussion: 


\section{Review of Economics and Development Studies, Vol. 7 (3) 2021, 465-474}

1) How human resource management practices have any relationship with perceived job performance?

2) How organizational commitment and work engagement mediate between the relationship of HRM practices and job performance?

3) How organizational commitment and work engagement has relationship with human resource management practices?

\section{Review of Literature}

This section deals with the previous studies related to this construct. Organizational commitment provides a strong sense of organizational identification among employees Affective commitment has a negative relationship with employee turnover intentions (Colquitt et al., 2013). In conjunction with Normative commitment (NC), which is positively associated to turnover intention, Employee attitudes and behaviors have been proven to be influenced by human resource strategies that emphasize the organization's concern for their well-being (Guchait \& Cho, 2010; Sungu, Weng, Hu, Kitule, \& Fang, 2020). According to Chang (2005), job security reflects the organization's dedication to its employees, and people reciprocate the commitment to the organization.

However, compensation for teachers is one of the most important HRM responsibilities, and it is described as the types of pay or benefits that employees receive as a result of their job. Appropriate remuneration can help a business attract, motivate, and retain skilled personnel. Salary has an impact on employees' social status, motivation, and loyalty, as well as productivity (Aswathappa, 2008).

Nevertheless, faculty believe that their efforts are paying off. In truth, the more autonomy a person perceives, the more responsible he or she will feel for the job results, and this is a source of employee motivation and job satisfaction (Allen, Armstrong, Reid, \& Riemenschneider, 2008).

Several studies looked at organizational commitment as a multifaceted characteristic that can be quantified in three ways: affective (emotional connection), continuous (cost perception), and normative (duty). These are the most frequently known dimensions of organizational commitment and are commonly employed (Klein et al., 2009). According to the findings, academic devotion is an important factor in achieving good academic achievement (Eisinga et al., 2010). For decades, academics and practitioners have focused on organizational commitment as a strategy to improve employee retention and performance.

All the individuals are not the same that's why human resource management practices are designed to extract maximum performance from the employees. Simultaneously affecting employee engagement, inventiveness, and dedication contributes in job performance (Yudianto et al., 2021). Organizational Commitment and Human Resource Management Practices that are implemented correctly always have a beneficial impact on employee commitment to the firm (Amponsah-Tawiah \& Mensah, 2016). Work engagement refers to an employee's excitement, passion, and absorption in their work (Bakker and Demerouti, 2008). Employees that are engaged have an enthusiastic and effective connection to their tasks, as well as a feeling of competence and effectiveness on the job and a satisfying mental state (Schaufeli et al., 2006).

Nonetheless, employees who are highly aware of leader integrity do not sense cynical at work and show stronger job engagement than those who are less conscious of leader integrity, some of the significant characteristics that may influence teachers' job performance are job satisfaction and organizational trust. Poor performers not only fail to deliver desired outcomes, but their unpleasant 


\section{Review of Economics and Development Studies, Vol. 7 (3) 2021, 465-474}

behaviour may also detract from other staff members' ability to accomplish their duties (Bashir, Bashir, Rana, Lambert, \& Vernallis, 2021; Muisyo et al., 2021; Sungu et al., 2020).

\section{Social Exchange Theory (SET)}

The theoretical model is based on Thibaut and Kelley's Social Exchange Theory (SET): which has been increasingly adopted as the theoretical foundation of turnover research to better understand employee-employer relationships (Coyle-Shapiro \& Conway, 2005). According to the Social Exchange Theory, all human connections are formed through idiosyncratic cost-benefit assessment and different assessment. The essence of this idea is what incentives/benefits an employee obtains from a specific relationship, and what expenses he or she pays to receive those rewards.

\section{Research Design and Methodology}

In our study, we, used a survey approach. A survey tactic had been applied in a logical approach. The survey method is the most common and well-known and commonly employed in exploratory and descriptive research. When collecting large amounts of data from a large population, surveys are a popular strategy. Frequently obtain through the use of a questionnaire for a survey, such that the information is institutionalized, allowing for easy investigation. Furthermore, when everything is said and done, the study system is considered as definitive by persons and is both extremely straightforward to reveal and obtain. Our research is based on a cross-sectional analysis. A cross-sectional study is one in which all research variables are measured in a brief period and data is collected at a single point in time. The cross-sectional study method is therefore appropriate for this study because the researcher is interested in learning about respondents' perceptions of human resource practices, trust, leader behavioral integrity, organizational commitment level, work engagement, turnover intention, and job performance behavior at a specific time.

To assess the structural link between variables, the current study uses a quantitative work technique. As a result, it's all about calculating correlations between variables. The primary goal of quantitative research is to investigate the cause-and-effect relationship between variables, as well as to provide generalization ability for the study's population. Sukamolson (2005), on the other hand, gives only a few grounds for using a quantitative approach in social science research. First, it delivers condensed data and inferences throughout the entire study population. Second, it aids in accurately describing the diversity of people's attitudes, and third, it allows for statistical comparison across different groups. Factor analysis and reliability analysis were performed to analyses the validity and reliability of the variables in order to observe the relationship between them. The response rate was calculated by multiplying the frequency and percentage of responses by the sample size calculated prior to data collection. The primary characteristics of the sample were described using descriptive statistics such as mean, median, standard deviation, frequencies, and percentage.

\subsection{Questionnaire Design}

A self-administrated questionnaire was adopted from different well established and freely available authentic sources. Human Resource Management Practices were measured by 16 items. It includes, four dimensions including faculty job autonomy (o5 items), faculty job security (03 items), faculty compensation ( 05 items) and faculty performance appraisal (o3 items). Organizational commitment only 8 items of affective commitment were taken 02 were removed due to weak factor loading. Work engagement was measured with og items and job performance was measured by o8 items. Total 41 items were collected to obtain the responses from faculty members working in public sector universities of Pakistan. A five-point Likert scale was applied which includes: 1= Strongly Disagree, 2= Disagree, 3= Neutral, 4= Agree, 5= Strongly Agree. 


\section{Results and Analysis}

Statistical model was tested by applying structural equation modeling on partial least squares by using SMART PLS licensed version 3. Figure 1.1 is provided as follow and represents the basic algorithm:

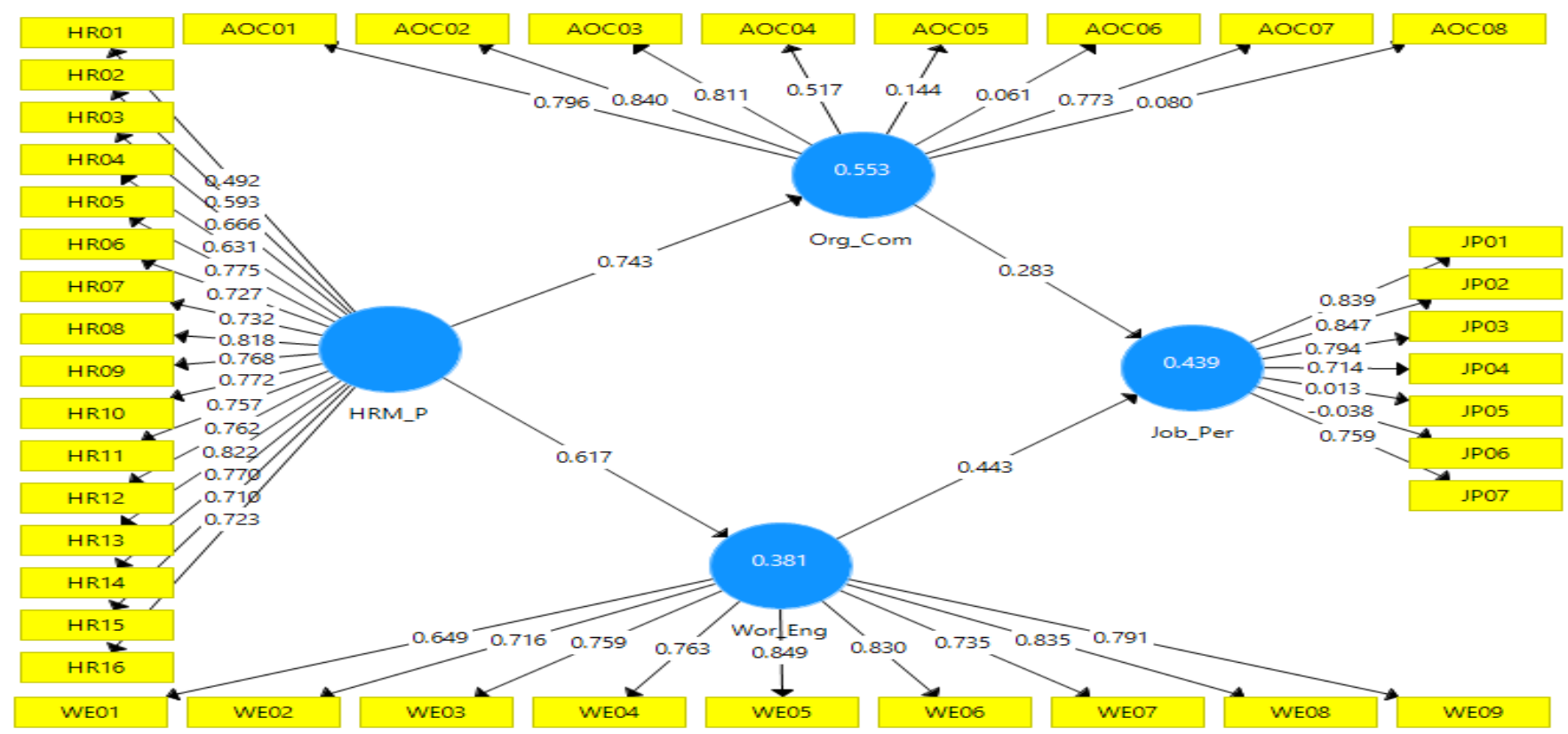

Figure:1.1 Basic Process Initialing

Some items that were not meeting the minimum threshold were removed and final picture is presented below. Figure 1.2 is presented below with minor changes as follow:

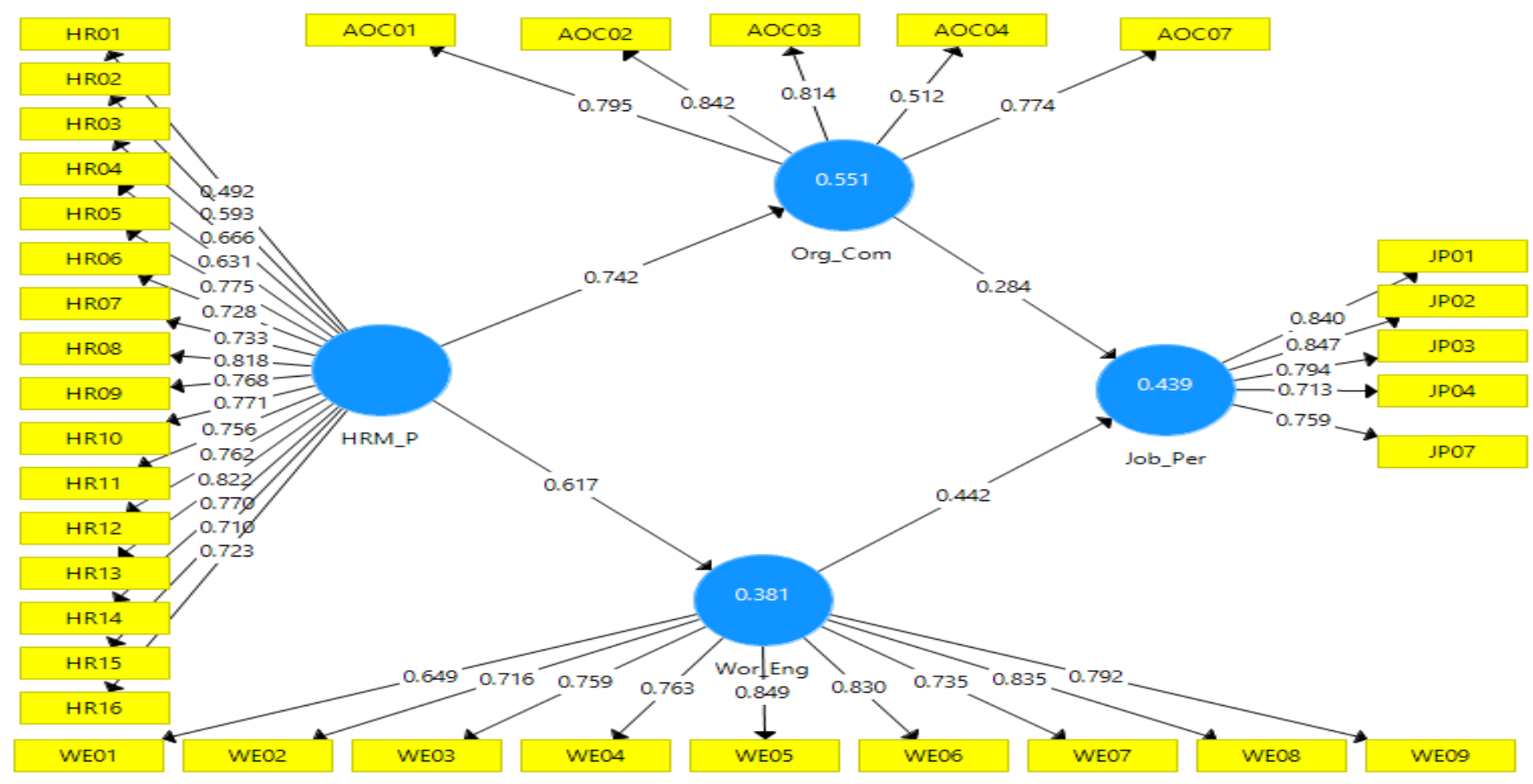

\section{Figure 1.2: After eliminating few items}

It can be view from the figure 1.2 that $r^{2}$ for the construct is 0.439 . Further details are provided below to clarify the empirical properties. 
Table: $\quad 1.1 \quad$ Construct Reliability and Validity

\begin{tabular}{|l|l|l|l|l|}
\hline & $\begin{array}{l}\text { Cronbach's } \\
\text { Alpha }\end{array}$ & rho_A & $\begin{array}{l}\text { Composite } \\
\text { Reliability }\end{array}$ & $\begin{array}{l}\text { Average Variance } \\
\text { Extracted (AVE) }\end{array}$ \\
\hline HRM_P & 0.938 & 0.942 & 0.946 & 0.525 \\
\hline Job_Per & 0.851 & 0.865 & 0.894 & 0.628 \\
\hline Org_Com & 0.806 & 0.833 & 0.867 & 0.573 \\
\hline Wor_Eng & 0.914 & 0.918 & 0.930 & 0.596 \\
\hline
\end{tabular}

The model has been examined for construct's reliability and convergent validity for this purpose Conbach's Alpha, rho_A, values are provided, the threshold for such criteria is $=>0.7$ and the values for the given criteria meets the threshold values. However Composite Reliability and AVE values are required $>=0.5$, which also meets the criteria. Therefore, the model is tested for further discriminant validity as below:

Table 1.2: Discriminant Validity (Fornell-Larcker Criterion)

\begin{tabular}{|l|l|l|l|l|}
\hline & HRM_P & Job_Per & Org_Com & Wor_Eng \\
\hline HRM_P & $\mathbf{0 . 7 2 5}$ & & & \\
\hline Job_Per & 0.568 & $\mathbf{0 . 7 9 2}$ & & \\
\hline Org_Com & 0.742 & 0.572 & $\mathbf{0 . 7 5 7}$ & \\
\hline Wor_Eng & 0.617 & 0.627 & 0.654 & $\mathbf{0 . 7 7 2}$ \\
\hline
\end{tabular}

The discriminant validity for the construct provided as above have minor issues such as the values of organization commitment are slightly higher than the value 0.725 , in diagonal. This might be due to two items of affective commitment that have been removed during factor loading as the said values does not meet the threshold criteria of outer loading. However, the human behavior never remains the same minor variations in assessing human behaviors is possible (Hair, Sarstedt, Hopkins, \& Kuppelwieser, 2014).

Table 1.3: Model Fit Summary

\begin{tabular}{|l|l|l|}
\hline & Saturated Model & Estimated Model \\
\hline SRMR & 0.067 & 0.075 \\
\hline d_ULS & 2.806 & 3.583 \\
\hline d_G & 1.214 & 1.251 \\
\hline Chi-Square & 1105.296 & 1121.713 \\
\hline NFI & 0.753 & 0.749 \\
\hline
\end{tabular}


The model fit summary has been provided for the better understands with statical model and in easy prediction. The next table presents the selection criteriaas below:

Table 1.4: Selection Criteria

\begin{tabular}{|c|c|c|c|c|c|c|}
\hline & 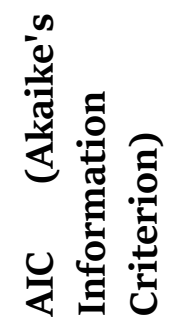 & 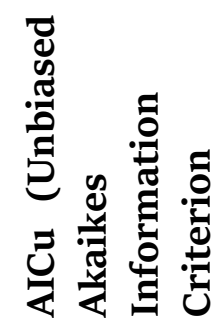 & 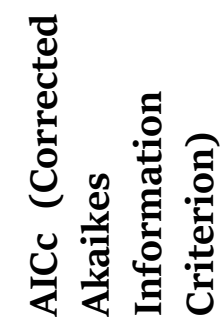 & 苞 & 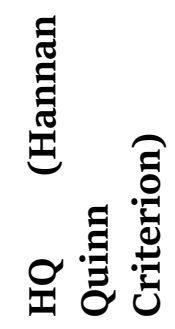 & 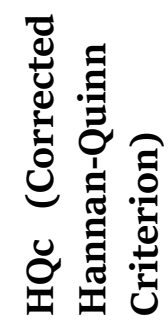 \\
\hline Job_Per & -100.356 & $-97 \cdot 331$ & 83.870 & -90.744 & -96.460 & -96.180 \\
\hline Org_Com & -142.759 & -140.748 & 41.376 & -136.351 & -140.161 & -140.013 \\
\hline Wor_Eng & -84.230 & -82.219 & $99 \cdot 905$ & -77.822 & -81.633 & -81.484 \\
\hline
\end{tabular}

All the necessary requirements have been dealt successfully to analyze the statistical model and the basic assumptions of partial least squares. Structural equation modeling technique has been applied using SMART PLS version 3. For that purpose, the below provided figure is provided for better elaboration.

Testing the hypothesis model T- statistics for the construct is provided below and can been seen that t-statistics are $=>1.96$ threshold. That represents the minimum desired values for making decision either to accept or reject the hypothesis.

Figure 1.3 is presented below for completing the research conclusions as below. It represents the T-statistics for the model as below:

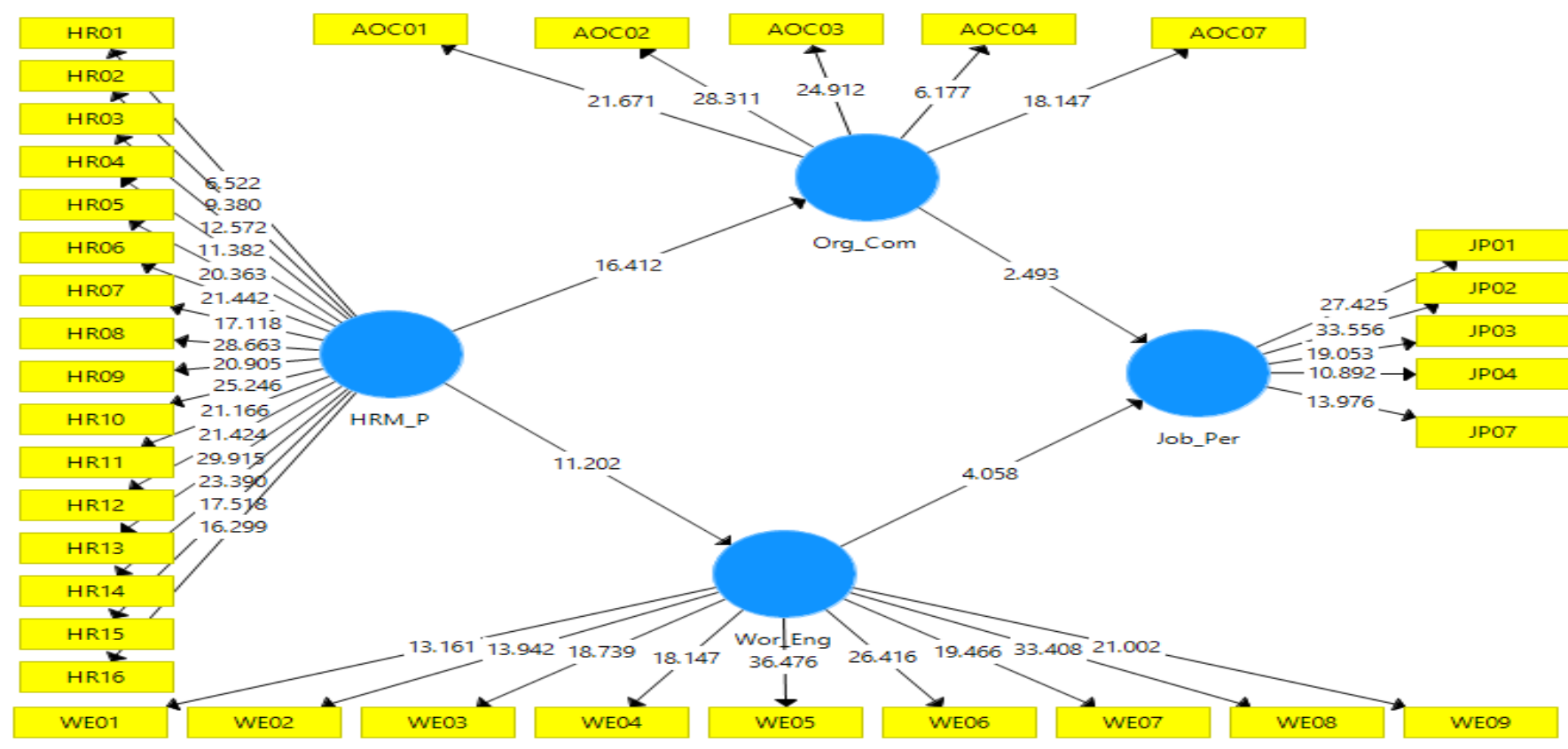

Figure: $\quad 1.3 \quad$ T-Statistics 
Table 1.5: T-Statistics for the statistical model

\begin{tabular}{|c|c|c|c|c|c|}
\hline & 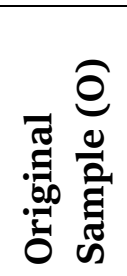 & 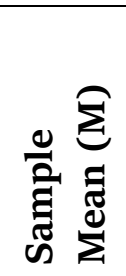 & 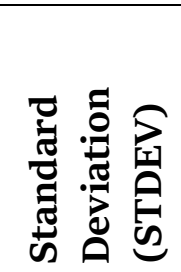 & 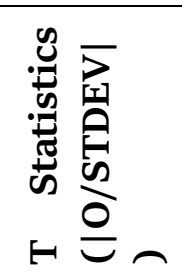 & 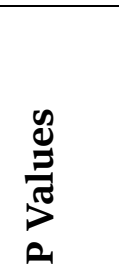 \\
\hline HRM_P -> Org_Com & 0.742 & 0.751 & 0.045 & 16.412 & 0.000 \\
\hline HRM_P -> Wor_Eng & 0.617 & 0.627 & 0.055 & 11.202 & 0.000 \\
\hline Org_Com -> Job_Per & 0.284 & 0.271 & 0.114 & 2.493 & 0.013 \\
\hline Wor_Eng -> Job_Per & 0.442 & 0.458 & 0.109 & 4.058 & 0.000 \\
\hline
\end{tabular}

The desired threshold of T-values for the acceptance and to reject the hypothesis was 1.96 or greater. The statical findings are evident that all four hypothesis are being accepted for final decision. The below mentioned tables provide the double mediating relationship and their specific indirect effect and total effect for convenience and easy understanding.

Table 1.6: Total Indirect Effect

\begin{tabular}{|c|c|c|c|c|c|}
\hline & 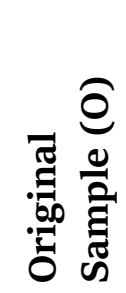 & 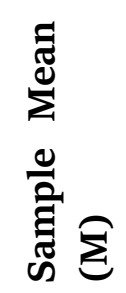 & 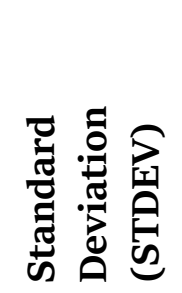 & 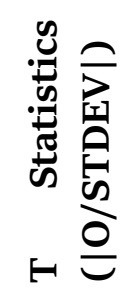 & 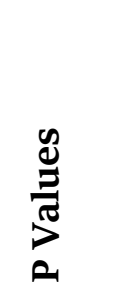 \\
\hline HRM_P -> Job_Per & 0.483 & 0.494 & 0.050 & 9.657 & 0.000 \\
\hline
\end{tabular}

Table 1.7 Specific Indirect Effects

\begin{tabular}{|c|c|c|c|c|c|}
\hline & 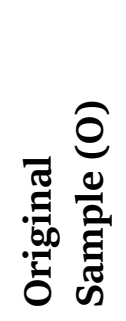 & 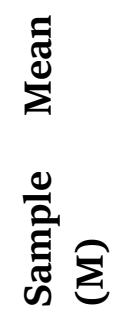 & 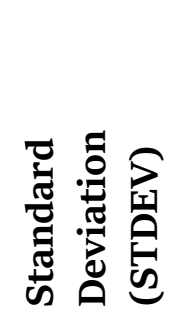 & 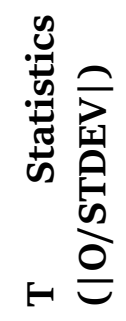 & $\frac{9}{\frac{d}{3}}$ \\
\hline HRM_P -> Wor_Eng -> Job_Per & 0.273 & 0.290 & 0.085 & 3.217 & 0.001 \\
\hline HRM_P -> Org_Com -> Job_Per & 0.210 & 0.203 & 0.086 & 2.435 & 0.015 \\
\hline
\end{tabular}


Table 1.8: Total effect

\begin{tabular}{|c|c|c|c|c|c|}
\hline & อ & 苞 胥 & 売 & H & 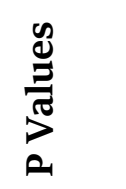 \\
\hline HRM_P -> Job_Per & 0.483 & 0.494 & 0.050 & 9.657 & 0.000 \\
\hline HRM_P -> Org_Com & 0.742 & 0.751 & 0.045 & 16.412 & 0.000 \\
\hline HRM_P -> Wor_Eng & 0.617 & 0.627 & 0.055 & 11.202 & 0.000 \\
\hline Org_Com -> Job_Per & 0.284 & 0.271 & 0.114 & 2.493 & 0.013 \\
\hline Wor_Eng -> Job_Per & 0.442 & 0.458 & 0.109 & 4.058 & 0.000 \\
\hline
\end{tabular}

Table: 1.9 Final Decisions

\begin{tabular}{|l|l|l|}
\hline & T Statistic & Decision \\
\hline Human Resource Management Practices and Organizational Commitment & 16.412 & Accepted \\
\hline Human Resource Management Practices and Work Engagement & 11.202 & Accepted \\
\hline Organizational Commitment and Job Performance & 2.493 & Accepted \\
\hline Work Engagement and Job Performance & 4.058 & Accepted \\
\hline
\end{tabular}

\section{Conclusion and Future Recommendations}

The study has provided eight tables and three figures for easy understanding of the construct in the Pakistan's context. It has been found that work engagement and affective organizational commitment has partially mediating relationship with human resource management practices and job performance. Due to some financial and time constraints the researchers remained unable to cover private sector universities, new studies might work for private sector HEIs. Furthermore, a qualitative research study might be designed to generalize the phenomena. As $\mathrm{r}^{2}$ is only $43.9 \%$, that means $56.1 \%$ portion remained uncover in this study. The future studies may work for other unexplored factors.

\section{References}

Aina, C., Bratti, M., \& Lippo, E. (2021). Ranking high schools using university student performance in Italy. Economia Politica, 38(1), 293-321. https://doi.org/10.1007/s40888-020-00208-2

Baltaru, R. D. (2019). Do non-academic professionals enhance universities' performance? Reputation vs. organisation. Studies in Higher Education, 44(7), 1183-1196. https://doi.org/10.1080/03075079.2017.1421156

Bashir, A., Bashir, S., Rana, K., Lambert, P., \& Vernallis, A. (2021). Post-COVID-19 Adaptations; the Shifts Towards Online Learning, Hybrid Course Delivery and the Implications for Biosciences Courses in the Higher Education Setting. Frontiers in Education, 6, 310. https://doi.org/10.3389/FEDUC.2021.711619/BIBTEX

Chunyu, Z., \& Liping, L. (2021). The effect of job crafting to job performance. Knowledge Management Research and Practice, 253-262. https://doi.org/10.1080/14778238.2020.1762517

Colquitt, J. a, Scott, B. a, Rodell, J. B., Long, D. M., Zapata, C. P., Conlon, D. E., \& Wesson, M. J. (2013). Justice at the millennium, a decade later: a meta-analytic test of social exchange and affect-based perspectives. The Journal of Applied Psychology, 98(2), 199-236. https://doi.org/10.1037/aoo31757 


\section{Review of Economics and Development Studies, Vol. 7 (3) 2021, 465-474}

Côté, K., Lauzier, M., \& Stinglhamber, F. (2021). The relationship between presenteeism and job satisfaction: A mediated moderation model using work engagement and perceived organizational support. European Management Journal, 39(2), 270-278. https://doi.org/10.1016/j.emj.2020.09.001

Gieter, S. De, Hofmans, J., \& Pepermans, R. (2011). Revisiting the impact of job satisfaction and organizational commitment on nurse turnover intention: an individual differences analysis. International Journal of Nursing Studies, 48(12), 1562-1569. https://doi.org/10.1016/j.ijnurstu.2011.06.007

Guchait, P., \& Cho, S. (2010). The impact of human resource management practices on intention to leave of employees in the service industry in India: the mediating role of organizational commitment. The International Journal of Human Resource Management, 21(8), 12281247. https://doi.org/10.1080/o9585192.2010.483845

Hair, J., Sarstedt, M., Hopkins, L., \& Kuppelwieser, V. (2014). Partial Least Squares Structural Equation Modeling (PLS-SEM): An Emerging Tool in Business Research. European Business Review, 26(2), 1. https://doi.org/10.1108/EBR-10-2013-0128

Kaur, H. (2011). Impact of Human Resource Factors on Perceived Environmental Performance: an Empirical Analysis of a Sample of ISO 14001 EMS Companies in Malaysia. Journal of Public Administration and Governance, 1(1), 174-196. https://doi.org/10.5539/jsd.v4n1p211

Li, Y., Liu, Z., Qin, K., Cui, J., Zeng, X., Ji, M., ... Li, Y. (2021). Organizational trust and safety operation behavior in airline pilots: The mediating effects of organizational identification and organizational commitment. Journal of Air Transport Management, 92(January), 102018. https://doi.org/10.1016/j.jairtraman.2021.102018

Loan, L. T. M. (2020). The influence of organizational commitment on employees' job performance: The mediating role of job satisfaction. Management Science Letters, 10(14), 3307-3312. https://doi.org/10.5267/j.msl.2020.6.007

Muisyo, P. K., Qin, S., Ho, T. H., \& Julius, M. M. (2021). The effect of green HRM practices on green competitive advantage of manufacturing firms. Journal of Manufacturing Technology Management, 33(1), 22-40. https://doi.org/10.1108/JMTM-10-2020-0388

Quaisar, I. K., Shukor, D. A. S., \& Soffian, D. S. S. I. (2016). Career Success and Organizational Justice as the Potential Predictors of Perceived University Performance : A Study from Public Sector Universities of Pakistan. European Journal of Business and Management, 8(16), 131-139.

Rabiul, M. K., \& Yean, T. F. (2021). Leadership styles, motivating language, and work engagement: An empirical investigation of the hotel industry. International Journal of Hospitality Management, 92(September 2020), 102712. https://doi.org/10.1016/j.ijhm.2020.102712

Sungu, L. J., Weng, Q., Hu, E., Kitule, J. A., \& Fang, Q. (2020). How Does Organizational Commitment Relate to Job Performance? A Conservation of Resource Perspective. Human Performance, 33(1), 52-69. https://doi.org/10.1080/08959285.2019.1699562

Utami, N. M. S., Sapta, I. K. S., Verawati, V., \& Astakoni, I. M. P. (2021). Relationship between Workplace Spirituality, Organizational Commitment and Organizational Citizenship Behavior. Journal of Asian Finance, Economics and Business, 8(1), 507-517. https://doi.org/10.13106/jafeb.2021.vol8.no1.507

Yudianto, I., Mulyani, S., Fahmi, M., \& Winarningsih, S. (2021). The influence of good university governance and intellectual capital on university performance in Indonesia. Academic Journal of Interdisciplinary Studies, 10(1), 57-70. https://doi.org/10.36941/ajis-2021-0oo6

Zhang, Q. Z., Jiang, S., Liu, R., \& Liu, H. C. (2020). An integrated decision-making model for analyzing key performance indicators in university performance management. Mathematics, 8(10), 1-16. https://doi.org/10.3390/math8101729 